\title{
Occurrence of bacteraemia following oral and maxillofacial surgical procedures in Port Harcourt, Nigeria
}

\author{
Omokaro Osaiyuwu
}

\begin{abstract}
Department of Oral and Maxillofacial Surgery, Rivers State University Teaching Hospital, Port Harcourt, Rivers State, Nigeria.
\end{abstract}

\begin{abstract}
Study Design: A prospective study of 130 patients attending the Government Dental and Maxillofacial Hospital (now Maxillofacial unit, Rivers State University Teaching Hospital), Port Harcourt, between August 2018 and September 2019.

Objective: To examine the factors that affect the occurrence of a bacteremia associated with oral and maxillofacial surgical procedures, and the types of bacteria causing this bacteremia, and establish the need or otherwise for prophylactic antibiotics in, 'at risk' patients.

Methods: 130 healthy adult patients requiring various oral and maxillofacial surgical procedures under local anesthesia using 2\% lidocaine with 1: 100,000 adrenaline, were screened bacteriologically to determine the occurrence of a bacteremia. 5 milliliters of venous blood was collected from the antecubital vein of each patient preoperatively and within 3 minutes postoperatively. The samples collected were cultured and bacteriological identification done and analyzed.

Results: Bacteremia was found in 43 (33.1\%) of 130 patients postoperatively. In patients undergoing extractions, bacteremia occurred more frequently when teeth were extracted due to inflammatory dental diseases. There was no statistical correlation between the occurrence of a bacteremia and the number of teeth extracted $(\mathrm{p}>0.05)$. Of the 70 isolates obtained postoperatively, $5(6.4 \%)$ were aerobes, $51(65.4 \%)$ were facultative anaerobes (including microaerophiles) and $14(17.9 \%)$ were anaerobes. Among the facultative anaerobes (including microaerophiles), the most frequently isolated bacteria genera were species of Staphylococcus (25.7\%), Streptococcus spp. (17.1\%) and Streptococcus viridans (15.7\%) and among the anaerobes, Bacteriodes spp. (8.6\%) were the most frequently isolated. All the isolates were sensitive to azithromycin, amikacin, imipenem and meropenem. However, $3(30 \%)$ of the isolates were resistant to amoxicillin, which is a commonly used drug for antimicrobial prophylaxis.

Conclusion: This study shows the occurrence of bacteremia in Nigerians following various oral and maxillofacial surgical procedures and that the observed bacteremia was not dependent on the patient's age or gender. This study emphasizes the need for antibiotic prophylaxis in those patients who are at risk of developing complications from bacteremia. Amoxicillin as this study shows will not be an effective antibiotic prophylactic agent in a majority of patients. The author therefore recommends the use of azithromycin as an alternative prophylactic agent in those patients.
\end{abstract}

Keywords: Bacteremia, bacteria isolates, antimicrobial prophylaxis, Port Harcourt, Nigeria.

DOI: bttps:// dx.doi.org/10.4314/abs.v21it.24

Cite as: Osaiyunu O. Occurrence of bacteraemia following oral and maxillofacial surgical procedures in Port Harcourt, Nigeria. Afri Health Sci. 2021;21(4):1692-700. bttps:// dx.doi.org/10.4314/abs.v21i4.24

\section{Introduction}

The presence of bacteria in the blood stream is referred to as bacteremia. In a healthy human, the blood stream is generally considered a sterile environment. Although bacteria nutrients are plentiful in blood, major anti-mi-

\section{Corresponding author: \\ Omokaro Osaiyuwu, Department of Oral and Maxillofacial Surgery, Rivers State University Teaching Hospital, Port Harcourt, Rivers State 500272, Nigeria. Email: oosaiyuwu@gmail.com}

crobial defenses, which include the circulating neutrophils and monocytes capable of phagocytosis, and the supporting components of humoral immunity including complements and immunoglobulins, help to mop up any bacteria that enter the blood stream. ${ }^{1}$

The oral environment is colonized by a number of species of bacteria, residing therein as commensals. They include anaerobes such as Peptostreptococcus, Propionibacterium, Bacteriodes, Prevotella and Fusobacterium spp., as well as facultative anaerobes such as Streptococcus, Actinomyces and Staphylococcus spp. ${ }^{2,3,4,5}$. Dental procedures, particularly dental extractions have been documented to cause

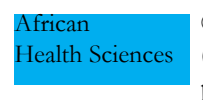

(C) 2021 Osaiyuwu O. Licensee African Health Sciences. This is an Open Access article distributed under the terms of the Creative commons Attribution License (https://creativecommons.org/licenses/BY/4.0), which permits unrestricted use, distribution, and reproduction in any medium, provided the original work is properly cited.

African Health Sciences, Vol 21 Issue 4, December, 2021 
the introduction of such oral bacteria into the blood stream. ${ }^{4,5,6,7}$

The occurrence of bacteremia following dental procedures has been documented ${ }^{2}$. Cawson, 1991 found that dental extractions regularly released bacteria from the gingival margins into the blood stream and was the first recognized source of bacteremia in dental practice ${ }^{6}$. Extractions are effective in producing bacteremia because of the immense number of bacteria surrounding the teeth and because extraction has a pumping action on the vessels of the periodontal region as they are alternately stretched and compressed by rocking of the tooth in the socket. ${ }^{6}$

The reported occurrence of bacteremia differs from study to study. Rahn et al., 1995, attributed this to factors such as the culture media and methods employed for anaerobic culture, the type of procedures performed, and the time of blood sampling ${ }^{7}$.

The occurrence of bacteremia after oral and maxillofacial procedures does not lead to any complication in healthy individuals. It can however, create serious problems in certain patients ${ }^{7}$. In individuals with congenital or acquired heart disease or those fitted with a valvular prosthesis, circulating bacteria may reach the defective endocardium and cause bacterial endocarditis ${ }^{8}$. Bacteremia can also be fatal in the elderly and children, ${ }^{9,}$, patients on immunosuppressant for organ transplant ${ }^{11}$, patients with uncontrolled diabetes ${ }^{12}$ and those with other valvular heart disease ${ }^{6}$. Bacteremia can also be fatal in patients with prosthetic joint replacement ${ }^{13}$ and in those with other body prostheses such as penile prosthesis ${ }^{14}$.

A mycotic aneurysm of the right carotid artery was reported in a 70-year-old man immediately after a complicated third molar extraction ${ }^{15}$. Ngapeth-Etoundi et al. ${ }^{16}$ reported septicemia and post-extraction coma in three patients. Kroppenstedt et al. ${ }^{17}$ reported a rare finding of an abscess in a pituitary tumor in a 69-year-old man four days after a tooth extraction. Larkin and Scott reported an unusual case of metastatic para spinal abscess and paraplegia as a consequence of simple dental extractions and subsequent bacteremia from a neglected mouth. ${ }^{18}$.

The literature is unclear about the nature and incidence of bacteremia from other oral surgical procedures, and the relationship of such bacteremia to dental disease. This study therefore seeks to establish the occurrence of bacteremia following various oral and maxillofacial surgical procedures, identify the implicated bacteria, and the effect of age, gender and types of dental pathology on such bacteremia. Furthermore, the study will determine the antibiogram of the implicated bacteria. It would also seek to establish the need or otherwise for prophylactic antibiotics in patients who are at risk of developing complications as a result of bacteremia.

\section{Materials and Methods}

This prospective study was conducted at the Government Dental and Maxillofacial Hospital (now Maxillofacial unit, Rivers State University Teaching Hospital), Port Harcourt. Port Harcourt is the capital city of Rivers State in the oil rich region of the Niger delta, southern Nigeria. It is located on latitude $4^{\circ} 46^{\prime} 38.71^{\prime \prime} \mathrm{N}$ and longitude $7^{\circ} 00^{\prime} 48.24^{\prime \prime} \mathrm{E}$. The hospital is a tertiary health facility that serves as a referral center for Rivers state and the neighboring states of Bayelsa, Abia and Akwa Ibom.

A total of 130 healthy medically fit adults aged 18-68 years attending the hospital between the periods of $\mathrm{Au}$ gust 2018 and September 2019, were sampled for this study. Patients, who have had antibiotics two weeks prior to presentation to the hospital, were excluded. Informed consent was obtained from the patients. Ethical clearance was obtained from the Ethics and research committee of the hospital, and informed consent was obtained from the patients. Patients were financially responsible for their treatment.

SPSS version 21, software was used for statistical analysis. Chi- square test was used to determine the relationship between dependent and independent variables. $\mathrm{P}$ value $<0.05$ was used to indicate significant association. Results are presented in tables 1 to 4 .

\section{Collection of Samples}

Peripheral blood samples were obtained from each patient by venepuncture of the antecubital vein of the left arm. 5 milliliters of venous blood was obtained aseptically preoperatively and another 5 milliliters within 3 minutes of completion of the procedure, and transferred into separate blood culture bottles containing nutrient broth and thioglycollate broth. Nutrient broth cultures were incubated aerobically, while the thioglycollate broth cultures were incubated anaerobically in gas pak jars at $37^{\circ} \mathrm{C}$ for 10 days.

Cultures with evidence of growth as indicated by turbidity and, or hemolysis were sub cultured. The nutrient broth cultures were sub cultured unto plates of blood 
agar, chocolate agar and MacConkey agar. The blood and MacConkey agar plates were incubated aerobically while the chocolate agar plates were incubated under increased carbon dioxide tension in candle jars at 37 degrees Celsius for $48 \mathrm{hrs}$. Thioglycollate blood cultures were sub cultured onto plates of blood agar and incubated anaerobically in gas pak jars for 48 hours. Bacterial isolates were identified by colony morphology, gram staining reaction, biochemical tests using catalase test, coagulase test, citrate utilization test (TSI) (OXOID, UK), Urease test $\left(\mathrm{BBL}^{\mathrm{TM}}\right)$ and motility indole lysine $(\mathrm{MIL})\left(\mathrm{BBL}^{\mathrm{TM}}\right)$ tests as outline by Cowan and Steel, $1993^{19}$.

\section{Antimicrobial sensitivity testing}

The Kirby- Bauer disk diffusion method was used to test bacteria susceptibility to antimicrobial agents. Commer- cially available multidisks (Sigma chemicals) containing the following antimicrobials: penicillin $\left(10^{\mu \mathrm{g}}\right)$, amikacin $(10 \mu \mathrm{g})$, ciprofloxacin $(5 \mu \mathrm{g})$, azithromycin $(15 \mu \mathrm{g})$, bacitracin $(10 \mu \mathrm{g})$, amoxicillin $(20 \mu \mathrm{g})$, metronidazole $(30 \mu \mathrm{g}$ ), imipenem $(10 \mu \mathrm{g})$, meropenem $(20 \mu \mathrm{g})$, were used on diagnostic sensitivity agar plate cultures of each isolate. Cultures were incubated as described earlier, and zones of inhibition after incubation were interpreted as outlined by Bauer et al., $1966^{20}$.

\section{Results}

A total 130 patients (mean age: $31.3 \pm 14.2$ years; range: 15-68 years) attending the Government dental and Maxillofacial Hospital (now maxillofacial unit of the Rivers State University Teaching Hospital), Port Harcourt were studied.

Table 1: Demographic and operative characteristics and the occurrence of Bacteremia

\begin{tabular}{|c|c|c|c|c|c|c|}
\hline \multirow{2}{*}{$\begin{array}{l}\text { Variable } \\
\text { Age }(\mathbf{N}=130)\end{array}$} & \multirow[t]{2}{*}{ Frequency } & \multirow[t]{2}{*}{$\begin{array}{l}\text { Percent } \\
\%\end{array}$} & \multicolumn{2}{|c|}{$\begin{array}{l}\text { Occurrence } \\
\text { of } \begin{array}{l}\text { Bacteremia } \\
n(\%)\end{array}\end{array}$} & \multirow[t]{2}{*}{$\chi^{2}$} & \multirow[t]{2}{*}{ P-value } \\
\hline & & & Yes & No & & \\
\hline$<25$ & 57 & 43.9 & $17(39.5)$ & $40(46.0)$ & 0.674 & 0.714 \\
\hline $25-49$ & 54 & 41.5 & $20(46.5)$ & $34(39.1)$ & & \\
\hline$\geq 50$ & 19 & 14.6 & $6(14.0)$ & $13(14.9)$ & & \\
\hline $\operatorname{Sex}(N=130)$ & & & & & & \\
\hline Male & 43 & 33.1 & $19(44.2)$ & $24(27.6)$ & 3.582 & 0.058 \\
\hline Female & 87 & 66.9 & $24(55.8)$ & $63(72.4)$ & & \\
\hline $\begin{array}{l}\text { Procedure } \\
(N=130)\end{array}$ & 44 & 33.8 & $15(34.9)$ & $29(33,3)$ & 21181 & 0001 \\
\hline Extraction & 18 & 13.8 & $5(11.6)$ & $13(14.9)$ & 21.101 & 0.001 \\
\hline Surgical extraction & 18 & 13.8 & $12(27.9)$ & $6(6.9)$ & & \\
\hline I \& D & 16 & 12.3 & $8(18.6)$ & $8(9.2)$ & & \\
\hline IMF & 22 & 16.9 & $3(7.0)$ & $19(21.8)$ & & \\
\hline Incisional biopsy & 12 & 9.2 & $0(0.0)$ & $12(13.8)$ & & \\
\hline Excisional biopsy & & & & & & \\
\hline $\begin{array}{l}\text { Duration of } \\
\text { procedure }\end{array}$ & & & & & & \\
\hline in $\operatorname{mins}(N=130)$ & 65 & 50.0 & $19(44.2)$ & $46(52.9)$ & 3.100 & 0.376 \\
\hline$<30$ & 45 & 34.6 & $14(32.6)$ & $31(35.6)$ & & \\
\hline $30-59$ & 10 & 7.7 & $5(11.6)$ & 5 (5.7) & & \\
\hline $60-90$ & 10 & 7.7 & $5(11.6)$ & $5(5.7)$ & & \\
\hline$>90$ & & & & & & \\
\hline $\begin{array}{l}\text { Indications for } \\
\text { extraction }(\mathrm{N}=62)\end{array}$ & & & & & & \\
\hline Inflammatory & & & $17(85.0)$ & $28(66.7)$ & 2.288 & 0.130 \\
\hline $\begin{array}{l}\text { diseases } \\
\text { Non- inflammatory } \\
\text { diseases }\end{array}$ & & & $3(15.0)$ & $14(33.3)$ & & \\
\hline $\begin{array}{l}\text { Number of teeth } \\
\text { extracted }(N=62) \\
1 \\
>1\end{array}$ & & & $\begin{array}{l}18(90) \\
2(10)\end{array}$ & $\begin{array}{c}36(85.7) \\
6(14.3)\end{array}$ & 0.221 & 0.638 \\
\hline
\end{tabular}

Mean Age $=31.3 \pm 14.2$ years (Range: $15-18$ )

Mean duration of procedure $=35.9 \pm 29.5$ mins (Range: $6-150$ ) 
There were $43(33.1 \%)$ males (mean age: $34.2 \pm 16.6$, range 18-68) and $87(66.9 \%)$ females (mean age: $29.9 \pm$ 12.8 , range $15-65)$. Forty- four $(33.8 \%)$ patients had intra-alveolar extractions, 18 (13.8\%) patients had surgical extraction, $22(16.9 \%)$ patients had incisional biopsy, 12 (9.2\%) patients had excisional biopsy, $16(12.3 \%)$ patients had inter-maxillary fixation done and 18 (13.8\%) patients had incision and drainage.

Table-2: Number and types of bacteria isolates from bacteraemia associated with sex

\begin{tabular}{|l|l|l|l|}
\hline & \multicolumn{2}{|c|}{ Sex } & TOTAL \\
\hline & Male & Female & n (\%) \\
\hline Aerobes & & & \\
\hline Providencia spp & 2 & 1 & $3(4.8)$ \\
\hline Alcaligenes & 0 & 2 & $2(3.2)$ \\
\hline Microaerophils & & & \\
\hline Staph aureus & 7 & 10 & $17(27.4)$ \\
\hline Strep viridans & 2 & 7 & $9(14.5)$ \\
\hline Diphtheroides & 1 & 1 & $2(3.2)$ \\
\hline Strep spp & 6 & 4 & $10(16.1)$ \\
\hline Coliforms & 4 & 1 & $5(8.1)$ \\
\hline Anaerobes & & & \\
\hline Bacteroides spp & 1 & 5 & $6(9.7)$ \\
\hline Anaerobic strep & 3 & 1 & $4(6.5)$ \\
\hline Clostridium spp & 1 & 3 & $4(6.5)$ \\
\hline $\begin{array}{l}\text { TOTAL } \\
\text { n (\%) }\end{array}$ & 27 & 35 & 62 \\
\hline
\end{tabular}

Table-3: Association between duration of procedure and occurrence of bacteraemia

\begin{tabular}{|l|l|l|l|l|}
\hline \multicolumn{1}{|c|}{ Variable } & \multicolumn{2}{|l|}{ Occurrence of bacteraemia } & \multirow{2}{*}{$\mathbf{X}^{2}$} & P-value \\
\cline { 2 - 3 } & Yes (n=43) & No (n=87) & & \\
\cline { 2 - 3 } & $\mathbf{M} \pm$ SD & M \pm SD & & \\
\hline $\begin{array}{c}\text { Duration of procedure in patients } \\
\text { that had extraction }\end{array}$ & $14.8 \pm 6.37$ & $14.9 \pm 6.17$ & -0.049 & 0.961 \\
\hline $\begin{array}{c}\text { Duration of procedure in patients } \\
\text { that had surgical extraction }\end{array}$ & $25.4 \pm 6.77$ & $29.5 \pm 9.33$ & -0.881 & 0.391 \\
\hline $\begin{array}{c}\text { Duration of procedure in patients } \\
\text { that had I \& D }\end{array}$ & $38.5 \pm 9.56$ & $37.5 \pm 5.24$ & 0.237 & 0.816 \\
\hline $\begin{array}{c}\text { Duration of procedure in patients } \\
\text { that had IMF }\end{array}$ & $103.1 \pm 15.80$ & $105 \pm 26.73$ & -0.171 & 0.867 \\
\hline $\begin{array}{c}\text { Duration of procedure in patients } \\
\text { that had biopsy }\end{array}$ & $35.0 \pm 22.9$ & $33.7 \pm 13.68$ & 0.144 & 0.886 \\
\hline
\end{tabular}

$\mathrm{M}=$ Mean, $\mathrm{SD}=$ Standard deviation

Five $(3.8 \%)$ cultures of blood samples taken preoperatively were positive. However, after surgery, bacteremia was found in $43(33.1 \%)$ of the 130 patients sampled. Bacteremia was found in $19(44.2 \%)$ of 43 males, and in $24(55.8 \%)$ of 87 females. There was no statistical significant difference in the occurrence of bacteremia between males and females $\mathrm{p}=0.058$.
A total of 70 isolates were obtained from the survey postoperatively. $5(6.4 \%)$ of the isolates were aerobes, $51(65.4 \%)$ were facultative anaerobes or microaerophiles and $14(17.9 \%)$ were anaerobes. The most frequently isolated anaerobes were Bacteriodes (6), followed by anaerobic Streptococcus spp. (4) and Clostridium spp. (5). Staphylococcus aureus (18) and non- hemolytic Streptococcus spp. (12) were the most frequently isolated, followed by $\alpha$-hemolytic Streptococcus spp. (11) among the facultative anaerobes. 
$27(43.5 \%)$ bacteria were isolated in males and 35 $(56.5 \%)$ were isolated in females. More bacteria were isolated in females than males though the difference was not statistically significant $\left(p=0.058 \chi^{2}=3.58\right)$. The occurrence of bacteremia was higher in those that had extraction as a result of inflammatory dental diseases
$17(85 \%)$ than in those that had extractions as a result of non-inflammatory diseases $3(15 \%)$. This difference was however not statistically significant $\left(p=0.130 \chi^{2}\right.$ $=2.29$ ).

The mean duration of procedure was $35.9 \pm 29.5$ (range6-150). $\mathrm{P}=0.376 \chi^{2}=3.10$

Table-4: Antibiotic susceptibility pattern of bacterial isolates

\begin{tabular}{|c|c|c|c|c|c|c|c|c|c|}
\hline \multirow{2}{*}{$\begin{array}{l}\text { Organism } \\
\text { isolated in the } \\
\text { study }\end{array}$} & \multicolumn{9}{|c|}{ Antibiotics Tested } \\
\hline & PEN & AMK & AMX & $\mathbf{A Z T}$ & BAC & CIP & MZT & IMP & MER \\
\hline \multicolumn{10}{|l|}{ Aerobes } \\
\hline Providencia spp & $\mathrm{S}$ & $\mathrm{S}$ & $\mathrm{S}$ & $\mathrm{S}$ & $\mathrm{S}$ & $\mathrm{S}$ & $\mathrm{S}$ & $\mathrm{S}$ & $\mathrm{S}$ \\
\hline Alcaligenes & $\mathrm{S}$ & $\mathrm{S}$ & $\mathrm{S}$ & $\mathrm{S}$ & $\mathrm{S}$ & $\mathrm{S}$ & $\mathrm{R}$ & $\mathrm{S}$ & $\mathrm{S}$ \\
\hline \multicolumn{10}{|l|}{ Microaerophils } \\
\hline Staph aureus & $\mathrm{R}$ & $\mathrm{S}$ & $\mathrm{R}$ & $\mathrm{S}$ & $\mathrm{S}$ & I & $\mathrm{S}$ & $\mathrm{S}$ & $\mathrm{S}$ \\
\hline Strep viridans & $\mathrm{S}$ & $\mathrm{S}$ & $\mathrm{S}$ & $\mathrm{S}$ & $\mathrm{S}$ & $\mathrm{S}$ & $\mathrm{S}$ & $\mathrm{S}$ & $\mathrm{S}$ \\
\hline Diphtheroides & $\mathrm{R}$ & $\mathrm{S}$ & $\mathrm{S}$ & $\mathrm{S}$ & $\mathrm{R}$ & $\mathrm{S}$ & $\mathrm{S}$ & $\mathrm{S}$ & $\mathrm{S}$ \\
\hline Strep spp & $\mathrm{S}$ & $\mathrm{S}$ & $\mathrm{S}$ & $\mathrm{S}$ & $\mathrm{S}$ & $\mathrm{S}$ & $\mathrm{S}$ & $\mathrm{S}$ & $\mathrm{S}$ \\
\hline Coliforms & $\mathrm{S}$ & $\mathrm{S}$ & $\mathrm{S}$ & $\mathrm{S}$ & $\mathrm{S}$ & $\mathrm{S}$ & $\mathrm{S}$ & $\mathrm{S}$ & $\mathrm{S}$ \\
\hline \multicolumn{10}{|l|}{ Anaerobes } \\
\hline Bacteroides spp & $\mathrm{R}$ & $\mathrm{S}$ & $\mathrm{I}$ & $\mathrm{S}$ & $\mathrm{R}$ & $\mathrm{I}$ & $\mathrm{S}$ & $\mathrm{S}$ & $\mathrm{S}$ \\
\hline Anaerobic strep & $\mathrm{R}$ & $\mathrm{S}$ & $\mathrm{S}$ & $\mathrm{S}$ & $\mathrm{S}$ & I & $\mathrm{S}$ & $\mathrm{S}$ & $\mathrm{S}$ \\
\hline Clostridium spp & $\mathrm{R}$ & $\mathrm{S}$ & $\mathrm{R}$ & $\mathrm{S}$ & $\mathrm{R}$ & $\mathrm{R}$ & $\mathrm{S}$ & $\mathrm{S}$ & $\mathrm{S}$ \\
\hline
\end{tabular}

\section{Discussion}

The result of this study shows a 3.8\% bacteria isolation rate preoperatively, which agrees with the observation of Guntheroth ${ }^{22}$ and that of Hogevik ${ }^{23}$. This could have been caused by the normal activities of gum chewing, brushing of teeth and eating carried out by the patients preoperatively, leading to the production of micro movements of the teeth within the sockets, thus, provoking bacteremia. In addition to the organisms that were isolated pre operatively from these patients, other genera were cultured postoperatively. This indicates that the surgical procedures provoked the introduction of additional bacteria into the blood stream.

Bacteria isolation rate of $33.1 \%$ was found postoperatively in patients studied. This is comparable with the result of the study by Osaiyuwu et al., ${ }^{5}$. Comparable bacteria isolation rates were obtained in two, separate studies by Roberts et al., who reported an occurrence of $38 \%$ and $38.7 \%$ following dental extractions in adults and children respectively. ${ }^{24,25}$

In this study, the presence of bacteremia was not age and gender dependent. This observation agrees with the findings of Osaiyuwu et al. ${ }^{5}$ in Nigeria and with that of Robert et al.10 in the United Kingdom. It however contrasts the findings of Okabe et al., ${ }^{3}$ in Japan and Lockhart et al.,41 in the United Kingdom.

In this study the occurrence of bacteremia was found to be dependent on the procedure. There was a significant association between the occurrence of bacteremia and the different oral surgical procedures $\left(p=0.001 \chi^{2}\right.$ 21.18). This finding agrees with those of Osaiyuwu et al. ${ }^{5}$, Robinson et al. ${ }^{26}$ and Okabe et al. ${ }^{3}$. They had identified the degree of surgical trauma, tissue injury and the type of disease the patient presented with as factors that could be responsible for increased occurrence of a bacteremia in patients undergoing extractions. The bacteria isolation rate in this study was particularly high 
in patients who had extractions and in those who had undergone incision and drainage and intermaxillary fixation. The most traumas to tissue in this study were caused by intermaxillary fixation, incisional biopsies and incision and drainage. Though the combined effect of soft tissue trauma with bone manipulation made inter-maxillary fixation the most traumatic procedure compared to other procedures, they produced less bacteremia than the latter. This was probably so because during incision and drainage soft tissue manipulation led to the introduction of bacteria into the blood stream from an already infected site or focus. This observation shows that bacteremia associated with oral and maxillofacial surgical procedures were not only affected by the degree of surgical trauma but also by the presence of infection at the site of operation. This also explains why patients requiring extractions who presented with inflammatory diseases such as pericoronitis, acute periapical periodontitis and chronic periodontitis had more bacteremia positive cases than those presenting with non-inflammatory diseases such as impacted teeth and supernumeraries.

In this study there was no statistically significant association between the duration of the procedures and the occurrence of bacteremia. This contrasts the findings of Okabe et al. ${ }^{3}$. They found a significantly higher occurrence of a bacteremia when the duration of the procedure lasted more than 100 minutes, than in shorter durations of operation. This is perhaps due to the fact that those procedures that took longer to complete, and that theoretically would have caused more tissue damage, and therefore, more bacteremia were less likely to be infected with the consequent effect of fewer bacteria introduced into the blood stream.

Okell and Elliot first investigated the type of bacteria involved in bacteremia associated with tooth extraction. In those days Streptococcus spp. were the isolates most commonly found in association with tooth extraction ${ }^{33}$. Similar bacteria genera were isolated in this study, facultative anaerobes being the most frequently isolated bacteria. $17.7 \%$ of the isolates were anaerobes. This contrasts the study by Otten et al., and those of Lee and $\mathrm{Kim}$, that found anaerobic bacteremia as high as $80 \%$ following dental extractions ${ }^{2,34}$. Similarly, Baltch et al., while studying bacteremia following dental cleaning in patients, found an anaerobic bacteremia of $74.6 \%$ and $25.4 \%$ aerobes $^{35}$. The low level of anaerobic bacteremia in this study is similar to the values reported by Roberts et al., ${ }^{25}$, who investigated bacteremia in children under- going four procedures used for conservative dentistry and found that $50 \%$ of the organisms isolated were facultative anaerobes (Viridans streptococcus). This low level of anaerobic bacteremia is further supported by the work of Amuradha and co- workers ${ }^{36}$, who reviewed cases of anaerobic bacteremia and found that of the 93 blood cultures they received with suspicion of anaerobic bacteremia over a period of two years, only $18.3 \%$ showed anaerobic growth.

The low level of anaerobic bacteremia seen is most likely because anaerobes are very fastidious organisms and most of them do not grow well in blood. Culture techniques also determine the level of anaerobic yield with newer and more sophisticated techniques giving higher yield. In this study traditional culture techniques were used and this could partly have accounted for the low yield of anaerobes. This agrees with the findings of Saito et al., ${ }^{37}$. Of the facultative anaerobes (including microaerophiles) the most frequently isolated genera were Staphylococcus aureus, Streptococcus spp., Streptococcus viridans, Diphtheroids and Coliforms. Among the anaerobes, Bacteroides, anaerobic Streptococcus and Clostridium spp. were more frequently isolated. These isolate are similar to the organisms isolated by Lucas and Roberts. ${ }^{38}$. Streptococcus and Staphylococcus were the most frequently isolated genera among facultative anaerobes. Bacteroides spp. was the most frequently isolated among obligate anaerobes, which agrees with the findings of Otten et al. ${ }^{2}$, Lee and $\mathrm{Kim}^{34}$, Okabe et al. ${ }^{3}$, Roberts et al. ${ }^{25}$, Amuradha et al. ${ }^{36}$, Bhatawadekar and Bhardwaj ${ }^{28}$, Saito et al. ${ }^{37}$ and Rajasuo et al. ${ }^{4}$. These organisms are characteristic of odontogenic bacteremia.

The endocarditis working party (EWP) of the British society for antimicrobial chemotherapy recommended that patient with congenital or acquired heart disease undergoing extraction of teeth, mucoperiosteal surgery or scaling should be given systemic antibiotic prophylaxis. ${ }^{39,40}$. The guidelines recommend the use of amoxicillin, and in patients allergic to penicillins, clindamycin should be used. In countries where oral suspension of clindamycin is not available, for example, the United Kingdom, azithromycin or clarithromycin can be used.

In this study the antibiotic sensitivity pattern of the isolated bacteria was examined. Azithromycin was found to be effective against both gram positive and gram negative isolates. Osaiyuwu et al. ${ }^{5}$ and Dagnew et al. ${ }^{42}$, reported ciprofloxacin as an effective antimicrobil agent 
The isolates in this study were found to be resistant to amoxicillin clavulanic acid, which contrasts the findings by Wasihun et al., ${ }^{43}$ but agrees with the findings of Osaiyuwu et al. ${ }^{5}$. The increased resistant antibiogram pattern of the isolates suggests a high resistance gene pool perhaps due to gross abuse and misuse of antibacterial agents. This is so because these antibacterial agents are readily available in this country as over the counter drugs.

This study is from a single tertiary health facility, and our findings may not have been representative of Port Harcourt city, since the city has another tertiary referral center. However, this study provides an insight into the occurrence of a bacteremia following oral surgical procedures, and the factors that affect such occurrence. One of the limitations of this study was the unavailability of newer blood culture methods such as the Bactec radiometric (460) system and the Bactec 760 system (Becton Dickson UK Ltd Oxford OX43LX United Kingdom). These systems would have ensured a higher culture yield, especially for the anaerobes. These systems detect the carbon dioxide $\left(\mathrm{CO}_{2}\right)$ produced by microorganisms growing in the defined culture medium. The carbon dioxide is measured using a radiometric method in the Bactec radiometric (460) and by infrared spectrophotometry in the Bactec 760 system. In addition, the Streptococci could not be speciated due to lack of the API Strep 20 system. The intensity of the bacteremia could not be determined because of the unavailability of the isolator system, which detects the colony forming units per milliliters of blood.

\section{Conclusion}

This study shows that bacteremia is frequently associated with maxillofacial surgical procedures. The occurrence of such bacteremia can have a deadly effect in those patients who are considered to be at risk of acquiring such infections. Such individuals include those with congenital heart disease, those fitted with a valvular prosthesis, those with defective endocardium and those on immunosuppressant for organ transplant. Therefore, antibiotic prophylaxis should be given to any patient who is suspected to be at risk of developing complications from bacteremia. The observed occurrence of a bacteremia is not affected by the patient's gender or age and that the differences in the occurrence of a bacteremia from procedure to procedure, is probably due to differences in the disease condition necessitating the procedure. The most frequently isolated bacteria were the facultative anaerobes (including microaerophiles).
The bacteria isolated are typical of those seen in other reported cases of odontogenic bacteremia. The anaerobic yield was low and finally, the efficacy of amoxicillin as a prophylactic antibiotic is seriously in doubt because of the observed resistance by some bacteria isolates.

The author therefore recommends the use of Azithromycin as the prophylactic antimicrobial of choice in patients who are susceptible to the effects of bacteremia.

\section{References}

1. Pedersen LM, Madsen OR, Gutschik E. Septicaemia caused by an unusual Neisseria meningitidis species following dental extraction. Scand. J. Infect. Dis. 1993; 25: 137-139.

2. Otten JE, Pelz K, Christmann G. Anaerobic bacteraemia following tooth extraction and removal of osteosynthesis plates. J. Oral Maxillofac. Surg. 1987; 45: 477-480.

3. Okabe K, Nakagawa K, Yamamoto E. Factors affecting the occurrence of bacteraemia associated with tooth extraction. Int. J. Oral Maxillofac. Surg. 1995 24: 239-242.

4. Rajasuo A, Perkki K, Nyfors S, Jousimies-Somer H, Meurman JH. Bacteraemia following Surgical Dental Extraction with an Emphasis on Anaerobic Strains. J. Dent. Res. 2004; 83: 170-174.

5. Osaiyuwu O, Aluyi HSA, Enabulele IO. Antibiotic Susceptibility Pattern of Aetiologic agents of Bacteremia Associated with Dental Extractions. Journal of Medical Laboratory Science. 2010 ;19: 17-22.

6. Cawson RA. Essentials of Dental Surgery and Pathology $5^{\text {th }}$ ed. Edinburgh, Churchill Livingstone. 1991; Pp. 192- 195.

7. Rahn R, Schneider S, Diehl O, Schafer V, Shah, PM. Preventing post-treatment bacteraemia: comparing topical povidone-iodine and Chlorhexidine. J. Am. Dent. Assoc. 1995; 126: 1145-1148.

8. Bender IB, Barkan MJ. Dental bacteraemia and its relationship to bacterial endocarditis: Preventive measures. Compend. Contin. Educ. Dent. 1989; 10: 472482.

9. Friedlander AH, Yoshikawa TT. Pathogenesis, management and prevention of infective endocarditis in the elderly. Oral Surg. Oral Med. Oral Pathol. 1990; 69: 177- 181.

10. Roberts GJ, Watts R, Longhurst P, Gardner P. Bacteraemia of dental origin and antimicrobial sensitivity following oral surgical procedures in children. Pediatr. Dent. 1998; 20: 28-36.

11. Ferretti GA, Ash RC, Brown AT. Chlorhexidine for prophylaxis against oral infections and associated 
complications in patients receiving bone marrow transplants. J. Am. Dent. Assoc. 1987; 114: 461- 467.

12. Li X, Kolltveit KM, Tronstad L, Olsen I. Systemic diseases caused by oral infection. Clin. Microbiol. Rev. 2000; 13: 547-558.

13. Waldman BJ, Mont MA, Hungerford DS. Total Knee arthroplasty infections associated with dental procedures. Clin. Orthop. 1997; 343: 164-172.

14. Field EA, Martin MV. Need for antibiotic prophylaxis for dental patients with penile prostheses. Br. Dent. J. 1990; 164:75.

15. Knouse MC, Madeira RG, Celani VJ. Pseudomonas aeruginosa causing a right carotid artery mycotic aneurysm after a dental extraction procedure. Mayo Clin. Proc. 2003; 77: 1125-1130.

16. Ngapeth-Etoundi M, Ela GA, Itoua ES, Obounou A. Septicaemia of dental origin and post extraction coma: A report of 3 cases. Odontostomatol. Trop. $2001 ; 24: 18$.

17. Kroppenstedt SN, Liebig T, Mueller W, Graf KJ, Lanksch WR, Unterberg AW. Secondary abscess formation in pituitary adenoma after tooth extraction. A case report .J. Neurosurg. 2001; 94: 335-338.

18. Larkin EB, Scott SD. Metastatic Paraspinal abscess and paraplegia secondary to dental extraction. $\mathrm{Br}$. Dent. J. 1994; 177: 340-342.

19. Cowan ST, Steel KJ. Manual for the identification of medical bacteria. 3rd edition. Cambridge University Press, 1993. 331pp.

20. Bauer AW, Kirby WM, Sherris JC, Trurch M. Antibiotic Susceptibility testing by a standardized single disk method. Am. J. Clin. Pathol. 1966; 36: 493-496.

21. Cawson RA. Infective endocarditis as a complication of dental treatment. Br. Dent. J. 1981; 151: 409414.

22. Guntheroth WG. How important are dental procedures as a cause of infective endocarditis? $\mathrm{Am}$. J. Cardiol. 1984; 54; 797-801.

23. Hogevik H, Olaison L, Andersson R. Epidemiologic aspects of infective endocarditis in an urban population: A 5-year prospective study. Medicine. 1995; 74: 324-329.

24. Roberts GJ, Radford P, Holt R. Prophylaxis of dental bacteraemia with oral amoxicillin in children. $\mathrm{Br}$. Dent.J. 1987; 162: 179-182.

25. Roberts GJ, Holzel H, Sury MRJ, Simmons NA, Gardner P, Longhurst P. Dental bacteraemia in children. Paediatr. Cardiol. 1997; 18: 24-27.

26. Robinson L, Kraus FW, Lazansky JP, Wheeler RE, Gordon S, Johnson V. Bacteraemia of dental origin. A study of the factors influencing occurrence and detection. Oral Surg. Oral Med. Oral Pathol. 1950; 3: 923-
926.

27. Heimdahl A, Hall G, Hedberg M, Sandberg H, Soder PO, Tuner K. Detection and quantitation by lysis-filtration of bacteraemia after different oral surgical procedures. J. Clin. Microbiol. 1990; 28: 2205-2209.

28. Bhatawadekar S, Bhardwaj R. Actinomycotic Bacteraemia after Dental Procedures. In. J. Med. Microbiol. 2002; 20: 23-25.

29. Pavek V, Broukal Z. The clinical significance of bacteraemia following tooth extraction. Zabn Mund Kieferbeilked Zentralbl 1990; 78: 403-406.

30. Roberts GJ, Gardner P, Simmons NA. Optimum sampling time for detection of dental bacteraemia in children. Int. J. Cardiol. 1992; 35: 311-315.

31. Aguada E, Olona IL, Salaza MB. Gingival degerming by povidone-iodine irrigation: bacteraemia reduction in extraction procedures. J. Philipp. Dent. Assoc. 1997; 49: 42-50.

32. Roberts GJ, Gardner P, Longhurst P, Black A, Lucas VS. Intensity of bacteraemia associated with conservative dental procedures in children. Br. Dent. J. 2000; 188: 95-98.

33. Palmer HD, Kempf M. Streptococcus viridans bacteraemia following extraction of teeth. JAMA.1939; 113: 1788- 1792.

34. Lee JG, Kim KS. A microbiologic study on anaerobic bacteraemia after dental extraction. Taehan Chikkwa Uisa Hyophoe Clin. 1990; 28:299-310.

35. Baltch AL, Schaffer C, Hammer MC, Sutphen NT, Smith RP, Conroy J, Shayegani M. Bacteraemia following dental cleaning in patients with and without penicillin prophylaxis. Am. Heart J. 1982; 104:1335-1339.

36. Anuradha DE, Saraswathi K, Gogate A. Anaerobic bacteraemia: a review of 17 cases. J. Postgrad. Med. 1998; 44: 63-66.

37. Saito T, Senda K, Takakura S, Fujihara N, Kudo $\mathrm{T}$ et al,. Anaerobic bacteraemia: the yield of positive anaerobic blood cultures: patient characteristics and potential risk factors. Clin. Chem. Lab. Med. 2003; 41: 293297.

38. Lucas VS, Roberts GJ. Odontogenic bacteraemia following tooth-cleaning procedures in children. Pediatr. Dentist. 2000; 15:203-210

39. Endocarditis Working Party of the British Society for Antimicrobial chemotherapy. Recommendations for endocarditis prophylaxis. J. Antimicrob. Chemother. 1993; 31:437-438.

40. Federation Dentaire Internationale. Guideline for antibiotic prophylaxis of infective endocarditis for dental patients with cardiovascular disease. Int. Dent. J. 1987; 37: 235-236.

41. Lockhart PB, Brennan MT, Kent ML, Norton 
HJ, Weinrib DA. Impact of amoxicillin prophylaxis on the incidence, nature and duration of bacteremia in children after intubation and dental procedures. Circulation. 2004; 109: 2878- 2884.

42. Dagnew M, Yismaw G, Gizachew M, Gadisa A, Abebe T, Tadesse T, et al. Bacterial profile and antimicrobial susceptibility pattern in septicemia suspected patients attending Gondar University Hospital,
Northwest Ethiopia. BMC Res Notes. 2013;6:283. doi: 10.1186/1756-0500-6-283.

43. Wasihun AG, Wlekidan LN, Gebremariam SA, Dejene TA, Welderufael AL, Haile TD, Muthupandian S. Bacteriological profile and antimicrobial susceptibility patterns of blood culture isolates among febrile patients in Mekelle Hospital, Northern Ethiopia. Springerplus. 2015 Jul 3; 4:314. Doi:10.1186/s40064-015-1056-x. PMID:26155453;PMCID: PMC4489972. 